\title{
Stanisław Kozicki o Action Francaise, Mussolinim, faszyzmie i stosunkach polsko-włoskich. Zapiski z rozmowy Michała Gwalberta Pawlikowskiego ze Stanisławem Kozickim [14 VIII 1928 r.]
}

opracowanie: Tomasz Sikorski i Adam Wątor

rezentowany zapis rozmowy, przeprowadzonej w Medyce przez Micha-
ła Gwalberta Pawlikowskiego ${ }^{1}$ ze Stanisławem Kozickim ${ }^{2}$, jest zaledwie

1 Michał Gwalbert Pawlikowski (1887-1970), publicysta, pisarz, kolekcjoner, wydawca. Ur. w Wiedniu, ukończył Wydział Filozoficzny Uniwersytetu Lwowskiego (1910), studiował w Akademii Rolniczej w Dublanach (1910). Dyrektor Towarzystwa Wydawniczego we Lwowie (od 1908), współpracownik „Ateneum Polskiego” (1908), wydawca „Lamusa” (1908-1933). Kierownik Biura Informacyjnego Centralnego Komitetu Narodowego (VIII 1914). Sekretarz S. Grabskiego we Lwowskim Komitecie Ratunkowym (II-VI 1915). Referent polityczny komitetu miejskiego SDN, redaktor „Zjednoczenia”. Następnie w Kijowie, pod firmą „Redakcji Zjednoczenia B”, kierował Biurem Informacyjnym, dostarczającym materiały dla Komitetu Narodowego Polskiego w Piotrogrodzie. Opracował statut Ligi Polskiej Pogotowia Wojennego. Członek Ligi Narodowej (od 1917). Redaktor „Przeglądu Polskiego” (od VI 1917), publikował w „Gazecie Polskiej”, sekretarz Ligi Narodów Uciśnionych, zorganizował Meeting Ligi Narodów Uciskanych przez Austro-Węgry (w Kijowie 29 XI 1917). Sekretarz generalny Rady Polskiej Zjednoczenia Międzypartyjnego w Moskwie (od IV 1918), uczestniczył w organizacji WP. W czasie walk polsko-ukraińskich kurier między Lwowem a Przemyślem i Krakowem. Pracował w biurze archiwalno-politycznym przy Tymczasowym Komitecie Rządzącym (XII 1918-III 1919). Redaktor „Pobudki”. W 1922 kierował akcją wyborczą Chrześcijańskiego Związku Jedności Narodowej w Małopolsce Wschodniej, współzałożyciel tajnego Komitetu „X”. Należał do Związku Ludowo Narodowego, Obozu Wielkiej Polski i Stronnictwa Narodowego. Współpracownik „Przeglądu Wszechpolskiego”, „Myśli Narodowej”, wydawca „Biblioteki Medyckiej". Pozostawił relacje o pracy w LN oraz wspomnienia i szkice Wczorajszy okop (Lwów 1921). Zm. w Londynie.

2 Stanisław Kozicki (1876-1958), dr nauk rolniczych, polityk, publicysta, dyplomata, członek Ligi Narodowej (od 1900), Stronnictwa Demokratyczno-Narodowego, Towarzy- 
drobnym fragmentem niepublikowanych memuarów (Wspomnienia i pamiętniki Michała Pawlikowskiego dotyczace wydarzeń z lat 1922-1927), zdeponowanych w Lwowskiej Bibliotece Naukowej im. Stefanyka (Archiwum Pawlikowskich, zespół 76 - cz. III, k. 459-460)³. Przeprowadzona 14 sierpnia 1928 r. prywatna rozmowa daje nam obraz poglądów Kozickiego na integralny nacjonalizm francuski (Action Francaise) ${ }^{4}$, włoski faszyzm, jego lidera

stwa Oświaty Narodowej, Związku Ludowo-Narodowego, Obozu Wielkiej Polski, Stronnictwa Narodowego, jeden z najbliższych współpracowników Romana Dmowskiego; w 1919 członek Komitetu Narodowego Polskiego w Paryżu, sekretarz generalny delegacji polskiej na konferencję w Wersalu, poseł na Sejm (1922-1925), senator RP (1928-1935), poseł RP w Rzymie (3 II 1926 - 1 XII 1926), redaktor i publicysta wielu czasopism, m.in.: „Gazety Polskiej”, „Gazety Warszawskiej”, „Kuriera Poznańskiego”, „Przeglądu Wszechpolskiego”, „Myśli Narodowej”. W czasie II wojny zaangażowany w działalność konspiracyjną (m.in. współpracownik Stefana Roweckiego „Grota”), po zakończeniu wojny publikował w czasopismach katolickich, np.: „Tygodniku Warszawskim”, „Kierunkach”, inwigilowany i prześladowany przez UB, autor wielu prac, m.in.: Sprawa granic Polski na konferencji pokojowej w Paryżu, [Warszawa 1921]; Dziedzictwo polityczne trzech wieszczów, [Warszawa 1949]; Historia Ligi Narodowej: (okres 1887-1907), [Londyn 1964]; Pamiętnik 1876-1939, opracowanie, przedmowa i przypisy Marian Mroczko [Słupsk 2009].

${ }^{3}$ Prezentowany maszynopis zawierał sporo błędów, tak językowych, stylistycznych (niedociągnięć natury frazeologicznej), jak i zniekształceń nazwisk, nazw własnych, miejscowości etc. Autorzy starali się owe błędy wyeliminować, dostosowując w sytuacjach wyjątkowych stylistykę i ortografię do wymogów współczesnej polszczyzny. Zmiany mające na celu modernizację pisowni dotyczą przede wszystkim literówek, interpunkcji, pisowni rozłącznie lub łącznie wyrazów i grup wyrazowych. Wszelkie skróty i zapisy uproszczone, występujące w materiale źródłowym, starano się rozwinąć, używając nawiasów klamrowych. W dokumencie pozostawiono nagłówek $z$ datacją. W przypisach objaśniono mniej znane wydarzenia i fakty historyczne, umieszczono noty bibliograficzne oraz odsyłacze do literatury przedmiotu.

${ }^{4}$ S. Kozicki po raz pierwszy zapoznał się z poglądami Action Francaise podczas swojego pobytu w Paryżu w 1904 i 1907 r. Do końca życia pozostał pod wpływem integralnego nacjonalizmu (zwłaszcza pisarstwa Charlesa Maurrasa i Maurice Barrèsa). Zob. np.: S. Kozicki, Od indywidualizmu do nacjonalizmu (Maurycy Barres), „Przegląd Narodowy” 1908, nr 11; tenże, Imperializm, „Przegląd Narodowy” 1910, nr 9; tenże, Nacjonalizm, „Przegląd Narodowy” 1911, nr 10; tenże, Charles Maurras i nacjonalizm francuski, „Przegląd Narodowy” 1914, nr 7; tenże Prądy polityczne we Francji wspótczesnej, „Przegląd Wszechpolski” 1922, nr 6; tenże, U podstaw, „Myśl Narodowa” 1931, nr 50; tenże, Słownik polityczny Karola Maurrasa, „Myśl Narodowa” 1934, nr 17; tenże, Co to jest „L’Action Francaise”, „Myśl Narodowa” 1936, nr 8; tenże, Bainville o Polsce, „Myśl Narodowa” 1937, nr 32. Zob. też: W. Plennikowski, Francuska ideologia nacjonalistyczna z przełomu 
Benito Mussoliniego i relacje polsko-włoskie. Ukazuje również kuluary usunięcia Kozickiego ze stanowiska posła RP przy Kwirynale (w Rzymie).

Tuż przed objęciem placówki dyplomatycznej we Włoszech Kozicki był czynnym politykiem narodowo-demokratycznym. Wybrany na posła w 1922 r., przez niespełna pięć miesięcy kierował klubem parlamentarnym Związku Ludowo-Narodowego. Po powrocie Stanisława Głąbińskiego do polityki parlamentarnej Kozicki zdecydował się ustąpić z tego stanowiska, robiąc miejsce dla nestora ruchu. Powrócił do czynnej publicystyki i za namową Romana Dmowskiego objął, co prawda na krótki czas (w 1924 r.), posadę redaktora „Gazety Warszawskiej”, głównego organu prasowego endecji ${ }^{5}$. Okazało się, że łączenie wymagającej wysiłku i poświęcenia działalności parlamentarnej z pracą w dużym i poczytnym dzienniku jest absorbujące. W tym okresie Kozicki pisał wiele, swoje artykuły, dotyczące głównie polityki zagranicznej i stosunków międzynarodowych, zamieszczał także w „Kurierze Poznańskim” i „Myśli Narodowej” (tygodniku założonym w 1921 r. i redagowanym przez Zygmunta Wasilewskiego) ${ }^{6}$.

W 1925 r. Kozickiemu zaproponowano objęcie placówki dyplomatycznej RP w Rzymie. Z inicjatywą wystąpił dyrektor Departamentu Politycznego w Wydziale Wschodnim MSZ Juliusz Łukasiewicz. Okazało się, że premier (a zarazem minister spraw zagranicznych) Aleksander hr. Skrzyński nie jest

XIX i XX wieku w świetle publicystyki Stanisława Kozickiego, „Annales Universitatis Mariae Curie-Skłodowska. Sectio F, Historia" 2002, nr 57, s. 37-49; A. Marszałek: Francja w myśli politycznej obozu narodowego (1918-1939), [w:] Dylematy II Rzeczypospolitej, red. A. Wojtas, Torun 1990, s. 61-102.

${ }_{5}$ Zob. U. Jakubowska, Oblicze ideowo-polityczne „Gazety Warszawskiej” i „Warszawskiego Dziennika Narodowego" w latach 1918-1939, Warszawa-Łódź 1988.

${ }^{6}$ Np.: S. Kozicki, W sprawie polskiej polityki zagranicznej, „Przegląd Wszechpolski” 1922, nr 1; tenże, Francja, Rosja i Polska, „Przegląd Wszechpolski” 1922, nr 3; tenże, Nowa faza sprawy żydowskiej, „Przegląd Wszechpolski” 1922, nr 9; tenże, Dwa programy, „Przegląd Wszechpolski” 1924, nr 7; tenże, Wobec projektów niemieckich rozbiorów Polski, „Przegląd Wszechpolski” 1925, nr 3; tenże, Listy poznańskie w sprawie Śląska, „Gazeta Warszawska” 25 X 1921; tenże, Listy poznańskie. Strażnica zachodnia, „Gazeta Warszawska” 26 X 1921; tenże, Drugie ostrzeżenie, „Przegląd Narodowy” 1921, nr 3; Listy poznańskie. Strażnica zachodnia, „Gazeta Warszawska” 26 X 1921. Na temat „Myśli Narodowej” obszernie P. Jastrzębski: „Myśl Narodowa” 1921-1939. Studium politologiczno-prasoznawcze, Warszawa 2012; tenże, Twórcy Myśli Narodowej w latach 1921-1926, „Dzieje Najnowsze" 2008, nr 2, s. 19-36. 
dostatecznie zadowolony z pracy dotychczasowego ministra pełnomocnego w Rzymie - Augusta Zaleskiego. Na "giełdzie nazwisk”, jako jego potencjalnych następców, wymieniano wówczas kilku kandydatów, wśród nich Stanisława Grabskiego, Władysława Jabłonowskiego (autora głośnej pracy Amica Italia. Rzecz o faszyzmie [Warszawa 1926]), także Macieja Loreta (historyka, radcy poselstwa RP w Watykanie). Ostatecznie w początkach lutego 1926 r. placówkę objął Kozicki i pozostał na niej do 19 grudnia tego samego roku.

Włochy i Rzym były dla Kozickiego miejscem wręcz wymarzonym. Od dawna był rozkochany w kulturze i historii tego państwa, co więcej, fascynował go faszyzm i sam Mussolini, czemu niejednokrotnie dawał wyraz w swoich artykułach i innych publikacjach. W spisanych po latach Pamiętnikach odnotował:

Gdy Mussolini przemawiał (...) to miał wyraz twarzy poważny, a nawet srogi, wysuwał naprzód dolną szczękę, wzrok miał groźny i przenikliwy (...) W gabinecie swoim natomiast, gdy przyjmował interesantów, miał na twarzy uśmiech, oczy wesołe, był pełen wdzięku i życzliwości. Bywałem u niego raz lub dwa razy na miesiąc, nie zdarzyło się ani razu, by mnie przyjął z twarzą ponurą w sposób opryskliwy. Lubiłem bardzo te wizyty, bo były przyjemne i interesujące. (...) Poznanie nacjonalizmu włoskiego umocniło mnie w przekonaniu, że jest to prąd ogólnoeuropejski, wynikający z przemian społecznych i kulturalnych w łonie narodów europejskich i że nasz nacjonalizm tak jak w ruchu demokratyczno-narodowym jest przejawem przemian podobnych w Polsce, związanej tysiącletnią tradycją z umysłowością zachodnioeuropejską. To umożliwiło mi zrozumienie momentu dziejowego, w którym żyłem i właściwą ocenę różnych przejawów w polityce narodów europejskich ${ }^{7}$.

Na placówce w Rzymie nie mógł się jednak Kozicki poszczycić dużymi osiągnięciami, poza częstymi i bliskimi kontaktami z Duce, politykami i ideologami faszystowskimi. Po dokonanym w maju 1926 r. przewrocie i przejęciu władzy przez Józefa Piłsudskiego miał pełną świadomość, że dni jego posłowania są policzone i niebawem zostanie odwołany. Było to tym bardziej prawdopodobne, że podobne „czystki” sięgnęły już innych polskich placówek dyplomatycznych w całej Europie. Jedną z przyczyn, która mogła przyspieszyć usunięcie Kozickiego, stał się brak jego reakcji na krytyczne wobec Piłsudskiego i sa-

7 S. Kozicki, Pamiętniki..., s. 533-534. 
nacji artykuły opublikowane w poczytnych i wpływowych pismach „Politica” i „Il Popolo d'Italia”, redagowanych przez Arnoldo Mussoliniego, brata Duce. Druga sprawa, która dolała już tylko oliwy do ognia, dotyczyła aresztowania w połowie czerwca 1926 r. w Rzymie Wincentego Rzymowskiego, korespondenta socjalistycznego „Robotnika”, za cykl krytycznych wobec faszystów artykułów ${ }^{8}$. Kozicki z polecenia Zaleskiego interweniował we włoskim MSZ, ale bezskutecznie. Dopiero minister spraw wewnętrznych Luigi Federzoni zgodził się, po rozmowie z posłem RP, na uwolnienie zatrzymanego. Wyjaśnienia w sprawie Rzymowskiego, złożone na łamach „Kuriera Warszawskiego”, nie wzmocniły pozycji Kozickiego. Tym bardziej, że władze polskie nie wykazywały wówczas większego zainteresowania ożywieniem relacji gospodarczych z Polską. W tej sytuacji Kozicki zajmował się sprawami bieżącymi, m.in. przygotowując polsko-włoską umowę w sprawach emigracyjnych, a we wrześniu podją - wraz z MSZ - zabiegi o poparcie Mussoliniego dla przyznania Polsce półstałego miejsca w Radzie Ligi Narodów.

Objęcie w październiku 1926 r. funkcji premiera przez Józefa Piłsudskiego przesądziło o losach Kozickiego. Otrzymał od ministra Zaleskiego list w tej kwestii. Z dniem 1 grudnia został odwołany. Na jego miejsce 20 grudnia 1926 r. został powołany piłsudczyk Roman Knoll (wcześniej poseł RP w Ankarze) ${ }^{9}$.

Po zakończeniu misji w Rzymie Kozicki udał się w dłuższą podróż, podczas której zwiedził południowe Włochy, zwłaszcza Sycylię, a następnie przebywał we Francji (w Vichy). Swoje obserwacje i wrażenia zawarł w książce: Na Sycylii (Wycieczka do Castel Mola. Spór Hermokratesa z Atenagorasem. Testament Cezara. Rózgi liktorskie. Pod przewodnictwem Wergiliusza), [Warszawa 1928].

Jako dyplomata nie odniósł sukcesu. Satysfakcję mógł odczuwać ze względu na otrzymane godności: Order Korony Włoskiej I Klasy, także Order Korony Rumuńskiej I Klasy. Latem 1927 r. powrócił do Poznania i włączył się aktywnie w życie polityczne.

8 Tamże, s. 537-538, 540-542. Także: M. Mroczko, Stanisław Kozicki (1876-1958). Biografia polityczna, Gdańsk 1999, s. 228-242.

9 Tamże, s. 242. 


\section{Stanisław Kozicki w Medyce 1928 [rok]}

\section{Rozmowy z Mussolinim - polityka zagraniczna Włoch. Cappela, Tama- ra (stosunek do piłsudczyzny). Masoneria paraliżuje interesy Polski}

14/8 Medyka. Jest u mnie Stanisław Kozicki (b[yły] sekretarz Kom[itetu] Nar[odowego] [Polskiego] w Paryżu, b[yły] ambasador przy Kwirynale, senator). Opowiada b[ardzo] ciekawe rzeczy o Action Francaise ${ }^{10}$, że to nieprawda, co mówił [Paul] Cazin ${ }^{11}$, że są tam b[ardzo] tędzy ludzie, na wszystko zdecydowani i Action [Francaise] bardzo się rozszerza. Watykan walczy z nimi najpierw dlatego, że prowadzi politykę masońską, a zrobiłby to samo i u nas, gdyby nie roztropne posunięcie [Romana] Dmowskiego ${ }^{12}$, a we Włoszech się boi - bo

10 Action Française (Akcja Francuska), francuska organizacja prawicy nacjonalistycznej, działająca (pod różnymi nazwami) od 1898 r. (synteza idei: monarchizmu, konserwatyzmu, nacjonalizmu). Przedstawiciele: Jacques Bainville, Maurice Barrès, Leon Daudet, Louis Dimer, Charles Maurras, Marius Plateau, Maurice Pujo, Georges Valois, Henri Vaugeois. Zob. szerzej: P. Boutang, Maurras, la destinée, l'œuvre, Éd. La Différence 1994; R. H. de la Montagne, Histoire de l'Action française, Éd. Amiot-Dumont, coll. Archives d'Histoire contemporaine, Paris 1950; A. Ch. d'Appolonia, L'extrême-droite en France, Bruxelles 1996; R. Girardet, Le Nationalisme francais : anthologie: 1871-1914, Paris 1983; V. Nguyen, Aux origines de l'Action française. Intelligence et politique à l'aube du XXe siècle, Paris 1991; E. Weber, L'Action française, Paris 1990; J. Eisler, Od monarchizmu do faszyzmu. Koncepcje polityczno-społeczne prawicy francuskiej 1918-1940, Warszawa 1987, A. Wielomski, Nacjonalizm francuski 1886-1940. Geneza, przemiany i istota filozofii politycznej, Warszawa 2007.

11 Paul Cazin (1881-1963), francuski pisarz, tłumacz (m.in. literatury polskiej). Zob.: K. Eberhardt, Posłowie, [w:] P. Cazin, Humanista na wojnie, Warszawa 1957; D. Knysz-Tomaszewska, H. Suwała, J. W. Borejsza, J. Odrowąż-Pieniążek, Dole i niedole francuskiego polonisty. Paul Cazin (1881-1963). Szkice, Warszawa 1999.

12 Roman Dmowski (1864-1939), główny ideolog polskiego nacjonalizmu, założyciel Narodowej Demokracji, od 1893 członek Ligi Narodowej, Stronnictwa Demokratyczno-Narodowego, Związku Ludowo-Narodowego, Obozu Wielkiej Polski, Stronnictwa Narodowego; w 1919 delegat RP na konferencje w Wersalu, w 1923 minister spraw zagranicznych. Zob. R. Wapiński, Roman Dmowski, Lublin 1988, K. Kawalec, Roman Dmowski, Wrocław 2002. 
[Benito] Mussolini ${ }^{13}$, jak o tym już wiem, wszędzie szachuje [Pietro] Gasparriego ${ }^{14}$. Ponadto owo wystąpienie przeciwko A[ction] F[raincaise] zaczęło się od szantażu, jakiego użył [Aristide] Briand ${ }^{15}$ wobec nuncjusza Mons[ignore] [Bonaventura] Caretti ${ }^{16}$, którego kompromitującą prywatną korespondencję miał w ręku. Wymógł na nim całą intrygę, a Caretti potem mimo to został odwołany i we Włoszech zamknięty w klasztorze. To opowiadał Kozickiemu Mussolini, który zresztą bardzo sprzyja $A[$ ction] $F$ [rancaise] i ma o nich dobre pojęcie.

Po zamachu majowym cała prasa włoska potępiła go, a najostrzej wystąpił Attilio Tamaro ${ }^{17}$, wiedeński korespondent „[Il] Popolo d’Italia”, redagowanego przez brata Mussoliniego ${ }^{18} \mathrm{w}$ artykule pt. Józef Piłsudsk ${ }^{19}$. [August]

13 Benito Amilcare Mussolini (1883-1945), włoski polityk, publicysta, ideolog i przywódca ruchu faszystowskiego, premier Włoch (1922-1943). Zob. J. Borejsza, Mussolini byt pierwszy..., Warszawa 1979; R. J. B. Bosworth, Mussolini, New York 2002; A. L. Cardoza, Benito Mussolini: the first fascist, Pearson Longman 2006; A. Lepre, La storia della repubblica di Mussolini; Salò: il tempo dell'odio e della violenza, Mondadori 1999; F. Bandini, Vita e morte segreta di Mussolini, Mondadori 1978; R. de Felice, Mussolini il rivoluzionario, Giulio Einaudi Editore 1965.

14 Pietro Gasparri (1852-1934), włoski duchowny, kardynał, specjalista w dziedzinie prawa kanonicznego, autor tzw. Katechizmu św. Piusa X. Zob. F. M. Taliani, Vita del Cardinale Pietro Gasparri, Segretario di Stato e povero prete, Milano 1938; L. Fiorelli, Il Cardinale Pietro Gasparri, Roma 1960.

15 Aristide Briand (1862-1932), francuski polityk, socjalista, wielokrotny premier i minister (1909-1929). Zob. Ch. Bellon, Aristide Briand et la naissance du centrisme, Paris 2000; Ch. Bellon, Aristide Briand: Parler pour agir, Paris 2016; R. Hesse, Aristide Briand, premier Européen, Paris 1939; B. Oudin, Aristide Briand, Paris 2016.

16 Bonaventura Ceretti (1872-1933), włoski duchowny, kardynał, dyplomata (m.in. w Meksyku, USA i Nowej Zelandii), od 1921 r. nuncjusz apostolski we Francji. Zob. E. Cerretti, Il Cardinale Bonaventura Cerretti, Roma 1939; V. de Marco, Un diplomatico vaticano all'Eliseo. Il cardinale Bonaventura Cerretti (1872-1933), Roma 1984.

17 Attilio Tamaro (1884-1956), włoski dziennikarz, publicysta i dyplomata (m.in. w Hamburgu i Bernie), autor Venti anni di storia 1922-1943, [Roma 1954].

18 Arnaldo Mussolini (1885-1931), włoski dziennikarz, publicysta, polityk, młodszy brat Benito Mussoliniego, dyrektor zarządzający „Il Popolo d’Italia”, redaktor i współpracownik: „Domenica dell'Agricoltore”; „Rivista Illustrata”; „Illustrazione Fascista”; „Bosco e Historia”. Zob. A. Pagliaro, Arnaldo Mussolini, Casa Editrice Nazionale 1938; M. Ingrassia, L'idea di fascismo in Arnaldo Mussolini, Palermo 1998; N. Fanizza, Maddalena Santoro e Arnaldo Mussolini. La storia d'amore che il duce voleva cancellare, Bari 2016.

19 Pilsudski, „Il Popolo d'Italia” 5 VI 1926. 
Zaleski ${ }^{20}$ polecił wtedy Kozickiemu zażądać exkuzy i odwołania. Kozicki poszedł do Mussoliniego i zastał go czytającego ten artykuł. Pokazał mu telegram Zaleskiego, na co Mussolini powiedział, że właściwie mógłby odrzec, że to sprawa prywatna, bo „[Il] Popolo [d'Italia]” nie jest organem urzędowym, jak w ogóle nie ma we Włoszech organu urzędowego, ale że gotów jest wpłynąć na „[Il] Popolo [d'Italia]” w tym kierunku, a nawet zgodził się przez posła włoskiego w Warszawie ${ }^{21}$ oświadczyć, że się z tym artykułem nie solidaryzuje. Tak też zrobił. Po oficjalnej rozmowie zauważył, że nie bardzo to wszystko rozumie, bo wprawdzie nie jest przeciwko opanowaniu władzy zamachami, ale ten kto to robi, musi po pierwsze wziąć na siebie całą odpowiedzialność, a po wtóre wiedzieć czego chce - tymczasem tutaj nie widzi się ani jednego, ani drugiego. Tamaro nie tylko nie dał za wygraną, ale w znacznie obszerniejszej i ostrzejszej formie wydrukował ten artykuł w piśmie „Politica", redagowanym przez Cappelę ${ }^{22}$, b[ardzo] wybitnego i bystrego człowieka. $\mathrm{Na}$ to Mussolini wezwał Cappelę i zażądał jeszcze przed drukiem cofnięcia artykułu, Cappela jednak odmówił, mówiąc, że jednak we Włoszech nie jest tak źle, aby urzędnicy obcych państw decydowali o sprawach redakcyjnych pism włoskich. Na artykuł zareagować chciał poseł włoski w Warszawie,

${ }^{20}$ August Zaleski (1883-1972), polityk, dyplomata, poseł RP we Włoszech (1922-1926), minister spraw zagranicznych (1926-1932; 1939-1941), prezydent RP na Uchodźstwie (1947-1972). Zob. P. Wandycz, Z Piłsudskim i Sikorskim. August Zaleski - minister spraw zagranicznych w latach 1926-1932 i 1939-1941, Warszawa 1999; R. Habielski, August Zaleski, [w:] Ministerstwo Spraw Zagranicznych II Rzeczypospolitej. Organizacja, polityka, ministrowie, Warszawa 2014, s. 317-326.

${ }^{21}$ Francesco Tommasini (1875-1945), włoski dyplomata, m.in. poseł nadzwyczajny i minister pełnomocny Włoch w Polsce (1919-1923), wolnomularz, autor La risurrezione del la Polonia, Milano 1925 (wyd. polskie: Odrodzenie Polski, Warszawa 1928). Zob. L. Monzali, Francesco Tommasini. L'Italia e la rinascita della Polonia indipendente, Roma 2018.

${ }^{22}$ Licinio Cappelli (1864-1952), włoski wydawca i księgarz (opublikował m.in. komplet dzieł Alfredo Oriani pod red. B. Mussoliniego i Classici del pensiero politico Giovanniego Gentile). Zob. Q. Cappelli, Licinio Cappelli, [in:] Personaggi della vita pubblica di Forlì e del circondario, Edizioni Quattroventi 1996; tenże, Licinio Cappelli [in:] Personaggi della vita pubblica di Forlì e circondario, (a cura di Lorenzo Bedeschi e Dino Mengozzi), vol. 1, Urbino, Edizioni Quattroventi 1996; G. Bonuzzi, Licinio Cappelli, Rocca San Casciano 1953; G. Tortorelli, Appunti sulla storia della casa editrice Cappelli, [in:] Il torchio e le torri, Bologna 2006. 
nowy wtedy [Francesco] Tommasini w artykule nadesłanym „Politice” Cappela posłał artykuł do Tamaro, ten jednak mianowany urzędnikiem, konsulem w Hamburgu, odpowiedział, że mu się nie wypada dalej w to wdawać, wobec czego Cappela wydrukowawszy kilka zdań z artykułu Tommasiniego, oświadczył redakcji, że stoi w tej sprawie bezwzględnie na stanowisku zajętym przez Tamarę w jego poprzednim artykule. Z Cappelą w ogóle należy się zbliżyć. Stoi on na stanowisku, że idea faszystowska, aby się utrzymać, musi budzić kulturę łacińską i nacjonalistyczną w innych krajach.

O Tadeuszu Romerze ${ }^{23}$ mówi Kozicki, że jest to człowiek zupełnie zdecydowanych i niezachwianych przekonań, katolik, konserwatysta, ale nie piłsudczyk, rozumny, ale ostrożny i zamknięty (nb. Romer musiał ocenić, że kiedy byłem w Rzymie nie tykałem z nim tych kwestii, nie chcąc wprowadzić go w niepotrzebny kłopot). [Roman] Knoll ${ }^{24}$ odwołany. Posłem mianowany [Stefan] Przezdziecki ${ }^{25} \mathrm{z}$ pomocą Romera.

W czasie strajku węglowego w Anglii zaproponował Kozickiemu Mussolini w formie uroczystej, że Włochy gotowe są brać 6 milionów ton węgla polskiego rocznie dla swych kolei. K[ozicki] odpowiedział z podziękowaniem, że zaraz o tym da znać rządowi, co też zrobił. Nazajutrz już zjawił się u niego Missiroli

${ }^{23}$ Tadeusz Ludwik Romer (1894-1978), polityk, dyplomata, podczas I wojny światowej Szwajcarskiego Komitetu Generalnego Pomocy Ofiarom Wojny w Polsce z siedzibą w Vevey, od jesieni 1919 osobisty sekretarz Romana Dmowskiego w Paryżu, radca poselstwa (następnie ambasady) RP w Rzymie (1928-1935), poseł RP w Portugalii (1935-1937), poseł RP w Japonii (1937-1941), ambasador RP w ZSRR (1943-1944), minister spraw zagranicznych (1943-1944). Zob. B. Szubtarska, Wstęp, [w:] Tadeusz Ludwik Romer. Listy do żony Zofii z Wańkowiczów (1942-1944), wstęp, wybór i oprac. B. Szubtarska, tłum. z francuskiego I. Goral, Warszawa 2011.

${ }^{24}$ Roman Knoll (1888-1946), polityk, piłsudczyk, dyplomata, m.in. poseł RP w Turcji (1924-1926), wiceminister spraw zagranicznych (1926), poseł RP w Rzymie (1926-1928), poseł RP w Berlinie (1928-1930). Zob. H. Bartoszewicz, The Russian Period in the Diplomatic Career of Roman Knoll, cz. 1, „Studia z Dziejów Rosji i Europy Środkowo-Wschodniej" 2004, z. 39; tenże, The Russian Period in the Diplomatic Career of Roman Knoll cz. 2, „Studia z Dziejów Rosji i Europy Środkowo-Wschodniej” 2005, z. 40; tenże, Roman Knoll. Polityk i dyplomata, Warszawa 2018.

${ }^{25}$ Stefan Przezdziecki (1879-1932), hrabia, ziemianin, prawnik, dyplomata w służbie rosyjskiej, następnie RP, dyrektor protokołu dyplomatycznego (1919-1928), ambasador RP w Rzymie (1929-1932), poseł na Sejm (1928-1932), Kawaler Maltański. Zob. A. Szklarska-Lohmannowa, Stefan Przezdziecki, „Polski Słownik Biograficzny” 1986, t. XXIX. 
(?). Bracia M[issiroli] ${ }^{26}$ finansowani przez [Giuseppe] Toeplitza ${ }^{27}$ mieli zastępstwa węglowe, który już o tej sprawie wiedział, z tym „że przecież nie można ich omijać”, którzy już „tyle” dla Polski zrobili i że w tej sprawie pojechał już brat Toeplitza do Warszawy ${ }^{28}$. Odpowiedzi od rządu polskiego Kozicki nie dostał [sic!] przez trzy miesiące! Po 3 miesiącach, kiedy już strajk w Anglii przygasał, odpowiedziano, że bardzo dobrze, a potem po 2 tygodniach wyparto się nawet tej odpowiedzi. Co zaś do Toeplitza, który przede wszystkim niemiecki węgiel do Włoch sprowadza, to rząd polski uległ po prostu jego politycznemu dyktatowi. Toeplitz, który finansuje pół Europy (kupił np. Bank Handlowy w Warszawie $)^{29}$, mówił Kozickiemu, że Polska jest terenem ogromnych możliwości inwestycyjnych, ale trzeba do tego najpierw... uregulowania pewnych spraw politycznych, a przede wszystkim skończyć z tym „niedorzecznym korytarzem" (T[oeplitz] mówi czysto po polsku).

Pewnego dnia zjawia się u K[ozickiego] jakiś „obywatel włoski”. „Mój ojciec - powiada - w Tarnopolu, czy gdzieś tam handlował różnymi rzeczami, którymi już nikt nie chciał handlować i zrobił majątek. Ja też mając tę żyłkę chciałem wprowadzić polskie rządowe kałuskie sole potasowe i napisałem do dyrekcji. Odpowiedziano mi, że od tego jest zastępstwo w Wiedniu. Napisałem do Wiednia, a tam mi odpowiedziano, żebym się zwrócił do zastępstwa w Mediolanie. Napisałem do Mediolanu, a stamtąd odpowiedziano mi, że oni nie handlują solami kałuskimi ${ }^{30}$, tylko strassfurtskimi ${ }^{31}$. Z tego wynika, że fa-

${ }^{26}$ Firma Fratelli Missiroli z Mediolanu (pod egidą Banco Commerciale Italiana) - importer węgla z Polski.

27 Józef Leopold Toeplitz (1866-1938), włoski bankier i przemysłowiec polskiego pochodzenia, dyrektor Banca Commerciale Italiana. Zob. E. Conti, Dal taccuino di un borghese, Garzanti 1946; L. Toeplitz, Il banchiere, Milano 1963; A. Iacopini, L'espansione della Banca Commerciale Italiana in Europa orientale durante il fascismo, „Studi di Storia Contemporanea: Spazi, percorsi e memorie” 2013, vol 13, no 3.

${ }^{28}$ W „Tygodniku Handlowym” z 4 III 1926 ukazał się wywiad z Teodorem Toeplitzem, zaangażowanym w handel węglem z Polski do Włoch z ramienia firmy „Hermann Meyer”. Głosy prasy, „Polonia-Italia” III 1927, nr 1.

${ }^{29}$ W 1927 Banca Commerciale Italiana zakupił 10\% akcji Banku Handlowego w Warszawie.

${ }^{30}$ Fabryka soli potasowych w Kałuszu, istniejąca od 1914. Zob. J. Kuhl, Z badań petrograficznych złoża solnego w Kałuszu, „Annales Societatis Geologorum Poloniae” 1930 (1929) vol. 6, s. 200-234.

31 Fabryka sody (Sodawerk) w Strassfurt, istniejąca od 1882 r. 
bryka strassfurtska wzięła, a nawet kupiła sobie zastępstwo we Włoszech na to, aby polskiej konkurencji skręcić kark". Kozicki napisał o tym do Warszawy. Nie otrzymał żadnej[!] odpowiedzi. W ogóle na każdym kroku widać, że za kulisami całego życia naiwnej, dziecinnej Polski siedzą i rządzą jakieś tajemne siły, które duszą i dławią systematycznie życie gospodarcze, przyszłość polityczną i kulturę społeczną. Kozicki ma przy sobie tajny protokół zebrania masońskiego, z którego wynika, że wszystko co się dziś dzieje, zgadza się z nim najściślej. Podatki progresywne i podatek spadkowy w ten sposób wyśrubowany (we Włoszech skasowany zupełnie) dąży do zniszczenia wielkich jednostek gospodarczych i osłabienia inicjatywy indywidualnej, sprawy żydowskie, mniejszościowe, szkolne, wszystko...

Obecnie zamach na młodzież na terenie sportowym, przez wzbudzanie międzynarodowych ambicji osobistych i używanie tych ludzi w zamian za to do swych celów (nb. Sichulski). Kto zna historię, ten może zaobserwować, że Polska od stu lat przez masonów rządzona, nie może się do dziś połapać, ale brnie coraz głębiej. Twórcy konstytucji 3 maja, będący w karbach masonerii, zmuszeni, czy przekonani przez swoje wyższe władze, robią fatalne przymierze z Prusami etc. (nb. dlatego też mogąc ex lex załatwić chaos z reformą rolną, nie robią).

Mussolini mówił Kozickiemu, że w wielkiej mierze przyszłość Włoch zależy od Polski. Bo jeśli Niemcy zwyciężą Polskę, to dadzą radę Francji, a jeśli zwyciężą Francję, to Włochy staną się parkiem spacerowym dla Niemców. M[ussolini] w ogóle ciągle i konsekwentnie i najwidoczniej szczerze podkreślał wspólność interesów Francji i Włoch, tym bardziej, że armia włoska nad Renem warta byłaby dla Francji załatwienia na korzyść Włoch spraw afrykańskich. Kozicki mu na to odpowiedział, że wobec tego i vice versa: przyszłość Polski leży w Afryce, co Mussolini zapamiętał i żegnając się po kilku miesiącach Kozickiemu to przypomniał.

We Francji jednak tymczasem rządzą masoni. Bezkarnie robi się agitację przeciw Polsce a na korzyść Niemiec. Przed kilku miesiącami ktoś znowu wytoczył wielką kampanię przeciw korytarzowi polskiemu i Pomorzu (nb. na to widocznie [Władysław] Folkierski ${ }^{32}$ potrzebował materiału).

32 Władysław Folkierski (1890-1961), filolog, publicysta, polityk. Ur. w Paryżu, profesor filologii romańskiej UJ 1 X 1920-1939. Członek PAU. W 1919 pracownik redakcji „L'Independance Polonaise” w Paryżu oraz oddziału wydawnictw i tłumaczeń Biura Prac 
Kozicki rad, że spotkał się u mnie z inicjatywą nawiązania łacińskiego kontaktu z zagranicą. Trzeba by doprowadzić do międzynarodowego zjazdu nacjonalistów: Francuzów (Action [Francaise]), faszystów, Polaków, Rumunów, bo Rumunia jako czwarta wchodzi w koncepcję Mussoliniego.

Kongresowych Delegacji Polskiej. Członek Ligi Narodowej (od 1926), ZLN, Wydziału Straży Narodowej (VI 1926), OWP (oboźny na woj. krakowskie od 4 XII 1926) i SN (prezes Rady Naczelnej od IV 1937). Po 1939 r. działacz emigracyjny, m.in.: zasiadał w Radzie Narodowej (1939-1941), minister prac kongresowych (1944-1947) oraz kierownik ministerstwa wyznań religijnych i oświecenia publicznego (1947-1949). 